Dept. of Food Hygiene and Control,

Faculty of Vet. Med. Cairo Univ.

\title{
EFFICACY OF DIFFERENT MARINADES ON TENDERNESS AND OVERALL QUALITY OF BUFFALO MEAT
}

(With 2 Tables and One Figure)

By

\section{GEHAN M. KASSEM; DALIA A. ZAHRAN* and FATMA H. ALI**}

* Health Radiation Research Dept. National Center for Radiation Research and Technology (NCRRT)

** Food Hygiene and Control Dept., Faculty of Vet. Med., Beni Seuf Univ.

(Received at 25/1/2009)

\section{تأثير طرق التمليح المختلفة علي جودة اللحم الجاموسي \\ جيهان محد عبل العزيز قاسم ، داليا عبل الحمبإ زهران ، فاطمة حسن محمد علئ}

تم عمل هذه الدراسة لتحسين جودة اللحم الجاموسي باستخدام طرق التمليح المختلفة. حيث

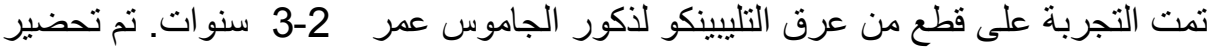

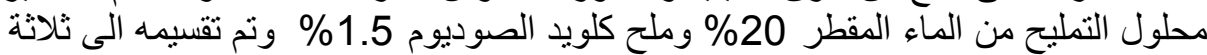

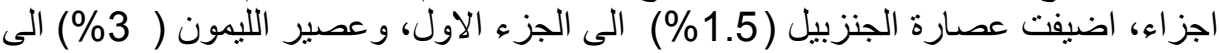

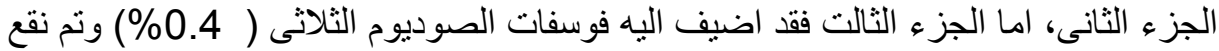

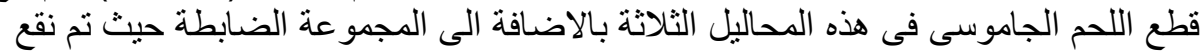

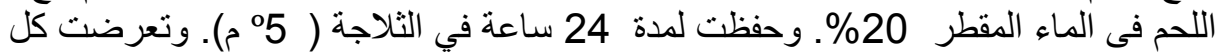

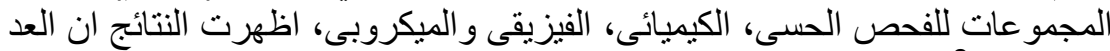

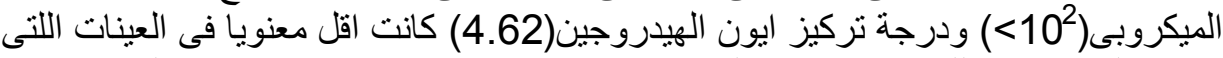

اضيف لها عصبر الليمون عن باقى المجموعات. و عند قياس مدى طر اوة انسجة العضلات

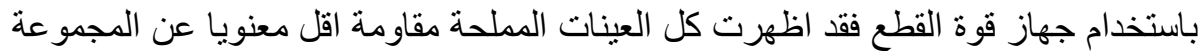

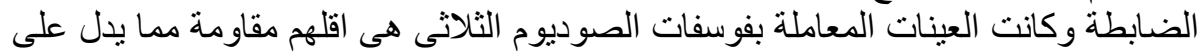

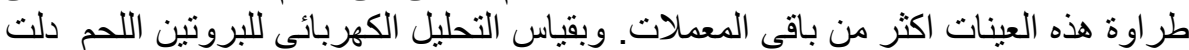

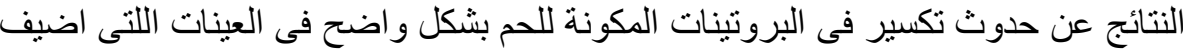

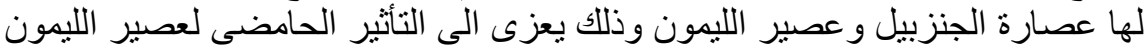

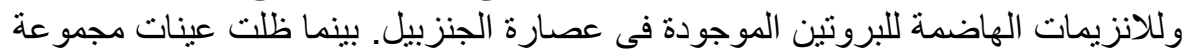

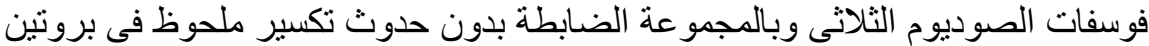
العضلات. كما اظهر الفحص الحسى تحسينا معنويا فى طر اوة و عصبرية كافة العينات 


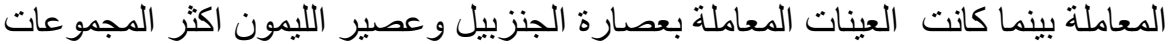

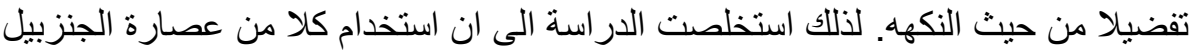

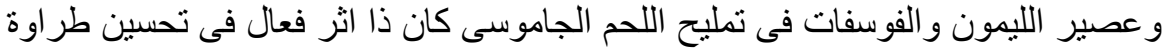

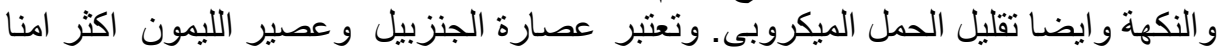
فى الاستخدام سو اء على مستوى التمليح فى المنازل و والمصانع.

\section{SUMMARY}

This study was conducted to improve tenderness and overall quality of less tender buffalo meat using different marinades. Semitendenosus muscles from 2-3 years old bull buffaloes were cut into chunks $3 \times 3 \times 3$ $\mathrm{cm}$ and marinated with either ginger extract (GE) $1.5 \%$ and $\mathrm{NaCl} 1.5 \%$ or lemon juice (LJ) $3 \%$ and $\mathrm{NaCl} 1.5 \%$ or Sodium tri-polyphosphate (STPP) $0.4 \%$ and $\mathrm{NaCl} 1.5 \%$ or distilled water $20 \%$ as control (C) for 24 hours at refrigerator shelf $\left(5^{\circ} \mathrm{C}\right)$. All groups were subjected to various physico-chemical and sensory evaluations. The sensory evaluation showed marked ( $p<0.05$ ) increase in flavour scores for GE and LJ marinated samples, while higher scores of tenderness and juiciness were noticed in GE and STPP marinated samples. Shear force values indicated significant reduction $(\mathrm{p}<0.05)$ in the values of GE $(10.28)$, LJ (10.57) and STPP (9.67) marinated samples. Cooking loss of the STPP marinated samples reduced significantly $(\mathrm{p}<0.05)$ compared with control, GE and LJ marinated samples. A marked decrease $(\mathrm{p}<0.05)$ in the aerobic plate count, psychrotrophic bacterial count and $\mathrm{pH}$ of $\mathrm{LJ}$ marinated samples were recoded. Electrophoretic pattern of muscle proteins revealed extensive proteolysis and reduction in the number of protein bands in GE and LJ marinated samples. TBARS decreased significantly $(\mathrm{p}<0.05)$ in GE and STPP marinated samples. The results obtained during this study pointed out that the use of GE, LJ or STPP marination solution could be an effective method of alleviating toughness associated with buffalo meat and improving the overall acceptability of buffalo meat eating quality.

Key words: Marination, buffalo meat, tenderness, ginger extract, lemon juice, Sodium tri-polyphosphate

\section{INTRODUCTION}

The world buffalo population is estimated to be approximately 130-150 million widely distributed throughout the world (FAO, 2004). Although buffalo meat has the advantage of low cholesterol content than 
beef, its meat is not preferred because of its less tender texture (Naveena et al., 2004). Tenderness has been identified as the most important factor affecting consumer satisfaction and perception of taste (Rust, 1998 and Robbins et al., 2003).

Marination with phosphate salts, sodium chloride, citrus juice and proteolytic enzymes are the most popular methods for meat tenderization (Vote et al., 2000; McGee et al., 2003; Naveena et al., 2004 and Baublits et al., 2005). Historically, the purpose of marinating meat was to preserve it. Marination is commonly used to increase yields by increasing water retention and improve meat quality characteristics, particularly meat tenderness (Brooks, 2007). The key ingredients for meat marinades are $\mathrm{NaCl}$ and phosphate (Northcutt, 1999 and Davis et al., 2004). Seasonings, sugar, oils, and organic acids such as vinegar or citric acid (lemon juice) are also incorporated in marination process (Wicker, et al., 1999 and Bauermeister and Mckee, 2005). Also, natural flavorings such as rosemary, ginger and thyme spice extract are added because of their flavoring attributes and strong antioxidative properties. Water is used to dissolve the non-meat ingredients and contributes to the tenderness and juiciness of the meat product and also increases yield. Salt is added at low levels to improve flavor and to increase the uniformity of solution distribution inside the meat product, and alkaline phosphates interact with meat proteins and increase their ability to hold moisture inside the products during cooking, which increases the juiciness of the cooked meat (Brooks, 2007). However, the complexity of the process along with ingredient composition and subsequent interaction often results in variability in product quality (Wicker et al., 1999).

Ginger has been investigated as a source of plant proteolytic enzyme (Lee et al., 1986; Syed Ziauddin et al., 1995 and Pawar et al., 2007). The ginger protease is a thiol proteinase with an optimum activity at $60^{\circ} \mathrm{C}$ (Naveena and Mendiratta, 2001). Thompson et al. (1973) and Naveena and Mendiratta (2001) pointed out that ginger extract is an effective meat tenderizer and the tenderization is achieved through its action on both myofibrillar and connective tissue components of meat.

The objectives of the present study are to evaluate the effectiveness of different marinades to overcome the toughness associated with buffalo's meat. Moreover, their effect on other meat quality parameters ( $\mathrm{pH}$, color, cooking loss, sensory attributes, lipid oxidation and microbial load) and protein degradation profile of meat were also studied. 


\section{MATERIALS and METHODS}

\section{Preparation and marination of samples}

Semitendenosus muscles from 2-3 years old bull buffaloes were collected within 10 hours post slaughter from local butchers. They were stored in refrigerator for 24 hour at $5^{\circ} \mathrm{C}$. After chilling, muscles were cut into chunks of approximately $3 \times 3 \times 3 \mathrm{~cm}$ size and divided into four groups of equal weight. The four groups were randomly allotted for marination.

The first group was soaked in $20 \%$ distilled water as control(C). While the other three groups were soaked in a marinade solution consisting of $1.5 \%$ sodium chloride, $20 \%$ distilled water in addition to either $1.5 \%$ ginger extract (Ginger extract (GE) was prepared from manual grinding and squeezing $100 \mathrm{gm}$ of peeled and sliced local fresh ginger, the resulted extract was approximately $50 \%$ of the original weight Lee et al., 1986) or 3\% lemon juice (LJ) or $0.4 \%$ Sodium tripolyphosphate (STPP) for the $2^{\text {nd }} 3^{\text {rd }}$ and $4^{\text {th }}$ group, respectively. After thorough mixing, buffalo chunks were kept on refrigerator shelf $\left(5^{\circ} \mathrm{C}\right)$ for 24 hours..

Raw samples were investigated for moisture content, $\mathrm{pH}$ value, color components ( $\mathrm{a}, \mathrm{b}$ and $\mathrm{L}$ ), lipid oxidation, microbial load (aerobic plate count (APC) and psychrotrophic bacterial count (PBC)) and electrophoretic pattern. While cooked samples (at $180^{\circ} \mathrm{C}$ for $20 \mathrm{~min}$. to attain an internal temperature of $70^{\circ} \mathrm{C}$ ) were examined for cooking loss, lipid oxidation, shear force and sensory attributes.

\section{Moisture\% and $\mathrm{pH}$ value}

Moisture content of the examined meat samples was determined as weight loss of two grams after drying in hot air oven for 18 hours at $102^{\circ} \mathrm{C}$ as recommended by AOAC (1990).

Twenty grams of the prepared sample were mixed with $20 \mathrm{ml}$ distilled water, then a digital $\mathrm{pH}$ meter (EU TECH England) with a calibrated probe type combined electrode (ORION/KNI pHE) was introduced into prepared mixture and the constant $\mathrm{pH}$ value was recorded as recommended by Ronald and Ronald (1991).

\section{Instrumental color measurement*}


Instrumental color determinations were made on the surfaces of Control and marinated samples using a micro color unit attached to a data station (Brano Lange -Germany) using the standard CIE LAB color system as follows: a-value (redness/green), b-value (yellowness/blue) and L-value (lightness/darkness,). Six readings were taken at various points on each sample (CIE, 1978).

\section{Lipid oxidation}

Lipid oxidation was assessed on both control and marinated samples before and after cooking. Thiobarbituric acid values (TBAvalue) were determined as recommended by Vynke (1970) using 7.5\% trichloroacetic acid (TCA) and freshly prepared 0.02 M TBA solution. The absorbance (A) of the developed red color was measured at wave length $538 \mathrm{~nm}$ against blank. Thiobarbituric acid reactive substances (TBARS) were calculated and expressed as $\mathrm{mg}$ malonaldehyde (mal)/ kg sample.

\section{Electrophoresis**}

Sodium dodecyl sulphate-polyacrylamide gel electrophoresis (SDS-PAGE) was carried out according to the methods of Laemmli (1970) and See and Jackowski (1993) using electrophoresis apparatus (Model. protean Xi Cell, BioRad USA). Five grams of minced meat was mixed with $50 \mathrm{ml} 0.01 \mathrm{~N}$ sodium phosphate buffer ( $\mathrm{pH} 7.0$ ) containing $1 \%$ SDS and $1 \%$ 2-mercaptoethanol and incubated at $37^{\circ} \mathrm{C}$ for 2 hours. The mixture was centrifuged at $1500 \mathrm{rpm}$ for $30 \mathrm{~min}$. An aliquot of supernatant was dialyzed overnight at room temperature $\left(25^{\circ} \mathrm{C}\right)$ against $0.1 \mathrm{~N}$ Sodium phosphate buffer containing $0.1 \%$ 2-mercaptoethanol. About $50 \mu \mathrm{m}$ of dialyzed solution was used for loading the gel. Electrophoresis was performed at a constant voltage mode of $100 \mathrm{~V} / \mathrm{slab}$ at $30 \mathrm{~mA}$ for 5-6 hours or until the tracking dye reached the lower end of the gel. The gel was removed and stained with Coomassie blue for 4-5 hours. The gels were then de-stained and photographed.

\section{APC and P BC}

Twenty five grams of each sample were aseptically homogenized in $225 \mathrm{ml}$ sterilized peptone water $0.01 \%$ using a stomacher (model 400, Seward laboratory, London) for one minute. The homogenate was serially diluted, inoculated onto standard plate count agar medium and incubated at $32^{\circ} \mathrm{C}$ for 48 hours for $\mathrm{APC}$ and at $7^{\circ} \mathrm{C}$ for 10 days for $\mathrm{PBC}$ (APHA, 1992).

\footnotetext{
*The test was preformed in National Center for Radiation Research and Technology (NCRRT).

**The test was preformed in Biotechnology Center. Fac. of Vet. Med. Cairo Univ.
} 


\section{Shear force*** and Cooking loss}

The samples were oven cooked at $180^{\circ} \mathrm{C}$ for 20 minutes to attain an internal temperature of $70^{\circ} \mathrm{C}$. Samples were chilled at refrigerator temperature over night and used for determination of tenderness (after equilibration at room temperature).

The shear force was measured with a blade $(68 \mathrm{~mm}$ widex 72 $\mathrm{mm}$ long $\times 3 \mathrm{~mm}$ thick) (Yoon, 2003) using Instron 1195 (England). The blade advanced $10 \mathrm{~mm} / \mathrm{min}$ and the pick up strength of the measuring head was $50 \mathrm{~kg}$ with the muscle fibers parallel to the direction of the blade. The results were expressed as $\mathrm{kg}$ force (f) to shear.

Cooking loss of the examined samples were determined, each sample was weighed prior to cooking. Upon completion of cooking, a final weight was obtained and cooking loss \% was determined as the difference between the fresh and cooked weight divided by the fresh weight.

\section{Sensory evaluation}

Meat chunks were cooked (as mentioned before) and served to the panel within 2 min after cooking. Samples were assessed for a number of sensory characteristics by seven panel members who are familiar with the characteristics to be evaluated (tenderness, juiciness, flavour intensity and overall acceptability). The sensory characteristics were evaluated using 8-point hedonic scale where one and eight were the extremes of each characteristic $(8=$ extremely tender, extremely juicy, extremely good flavour and extremely acceptable) (Keeton, 1983).

\section{Statistical analysis}

The values given in each treatment category are the mean values for three replicates. The data generated were analyzed by statistical software package using standard procedures for analysis of variance and Duncan multiple range test to compare the means and determine the effect of treatments (SAS, 1990). 


\section{RESULTS and DISCUSSION}

The results of physico-chemical tests are shown in Tables $1 \& 2$.

Table 1: Physico-chemical tests of raw samples

\begin{tabular}{|l|c|c|c|c|}
\hline \multicolumn{1}{|c|}{ Groups } & Control & GE & LJ & STPP \\
\hline Marameters & & & & \\
\hline PH value & $78.47^{\mathrm{a}}$ & $78.77^{\mathrm{a}}$ & $79.00^{\mathrm{a}}$ & $78.27^{\mathrm{a}}$ \\
\hline TBARS mg mal/kg & $5.6^{\mathrm{b}}$ & $5.5^{\mathrm{b}}$ & $4.62^{\mathrm{c}}$ & $5.88^{\mathrm{a}}$ \\
\hline APC $\log _{10} \mathrm{CFU} / \mathrm{g}$ & $0.19^{\mathrm{a}}$ & $0.14^{\mathrm{b}}$ & $0.20^{\mathrm{a}}$ & $0.12^{\mathrm{b}}$ \\
\hline PBC $\log _{10} \mathrm{CFU} / \mathrm{g}$ & $3.94^{\mathrm{b}}$ & $4.93^{\mathrm{a}}$ & $<10^{2 \mathrm{c}}$ & $3.47^{\mathrm{c}}$ \\
\hline Color & $3.72^{\mathrm{b}}$ & $5.03^{\mathrm{a}}$ & $<10^{2 \mathrm{~d}}$ & $2.28^{\mathrm{c}}$ \\
\hline a-value & $5.73^{\mathrm{a}}$ & $2.15^{\mathrm{c}}$ & $5.68^{\mathrm{a}}$ & $4.08^{\mathrm{b}}$ \\
\hline b-value & $5.42^{\mathrm{b}}$ & $3.40^{\mathrm{c}}$ & $7.58^{\mathrm{a}}$ & $1.99^{\mathrm{d}}$ \\
\hline L-value & $48.74^{\mathrm{b}}$ & $41.47^{\mathrm{c}}$ & $62.44^{\mathrm{a}}$ & $39.17^{\mathrm{c}}$ \\
\hline
\end{tabular}

APC: Aerobic plate count PBC: Psychrotrophs bacterial count

Means in the same row with unlike superscripts are different $(\mathrm{p}<0.05)$.

Table 2: Physico-chemical test and sensory attributes of cooked samples

\begin{tabular}{|l|c|c|c|c|}
\hline \multicolumn{1}{|c|}{ Groups } & Control & GE & LJ & STPP \\
\hline Parameters & & & & \\
\hline Cooking loss\% & $39.01^{\mathrm{a}}$ & $42.67^{\mathrm{a}}$ & $39.99^{\mathrm{a}}$ & $25.01^{\mathrm{b}}$ \\
\hline Shear force kg f & $0.57^{\mathrm{a}}$ & $0.22^{\mathrm{b}}$ & $0.27^{\mathrm{b}}$ & $0.13^{\mathrm{c}}$ \\
\hline Sensory attributes & $19.84^{\mathrm{a}}$ & $10.28^{\mathrm{b}}$ & $10.57^{\mathrm{b}}$ & $9.67^{\mathrm{b}}$ \\
\hline Flavor & & & & \\
\hline Tenderness & $4.00^{\mathrm{c}}$ & $6.67^{\mathrm{a}}$ & $7.17^{\mathrm{a}}$ & $5.50^{\mathrm{b}}$ \\
\hline Juiciness & $3.50^{\mathrm{b}}$ & $7.17^{\mathrm{a}}$ & $6.83^{\mathrm{a}}$ & $7.50^{\mathrm{a}}$ \\
\hline Overall acceptability & $3.50^{\mathrm{c}}$ & $7.00^{\mathrm{a}}$ & $5.67^{\mathrm{b}}$ & $7.67^{\mathrm{a}}$ \\
\hline
\end{tabular}

Means in the same row with unlike superscripts are different $(\mathrm{p}<0.05)$.

\section{Moisture and pH}


The moisture content of different marinated samples (Table 1) did not differ significantly $(\mathrm{p}<0.05)$ from that of control samples. Such results are in harmony with that obtained by Naveena et al. (2004). The interaction between marinades and meat chunks lead to a marked reduction in $\mathrm{pH}$ value of $\mathrm{LJ}$ marinated samples (4.62) this could be attributed to effect of high citric acid content in LJ marinade. Similar result was recorded by Burke and Monahan (2003), Aktas et al. (2004) and Rio et al. (2007). On the other hand STPP marinated samples showed the highest $\mathrm{pH}$ value (5.88), followed by GE marinated samples (5.5). These findings coincide with those of Pearson and Gillett (1996) and Rio et al. (2007) who emphasized the role of alkaline phosphate in the initial increase in $\mathrm{pH}$ of poultry and meat after treatment.

\section{Color}

It was clear from Table 1 that in terms of a-values (redness/green) GE (2.15) and STPP (4.08) marinated samples were less red $(\mathrm{p}<0.05)$ than the control (5.73) and LJ (5.68) marinated samples. This finding was in agreement with Robbins et al. (2002) and Baublits et al. (2006) who reported a general decline for enhanced versus untreated beef muscles which may be a function of increased water retention. Although the $b$-values increased significantly $(\mathrm{p}<0.05)$ in LJ marinated samples (7.58), it decreased significantly $(\mathrm{p}<0.05)$ in STPP (1.99) and GE (3.40) marinated samples compared with the control (5.42). This finding was in agreement with that of Lee et al. (1998). As expected, Lvalues of LJ marinated samples (62.44) were lighter $(\mathrm{p}<0.05)$ in color than all other samples. In this regard Swatland (1993) stated that the pale color of meat is influenced by the decline of $\mathrm{pH}$ and light scattering properties of the meat.

Although there were no significant difference $(\mathrm{p}<0.05)$ in Lvalues between GE and STPP marinated samples (39.17 and 41.47, respectively), there was a significant $(\mathrm{p}<0.05)$ decrease of their L-values compared with the control (48.74). In this regard, Bauermeister and Mckee (2005) indicated that lower L-values may be due to marination of meat, where lower L-values suggest that the meat was darker in color. Faustman and Cassens (1990) added that the general decline may be a function of the increasing ionic strength causing increased water retention which may cause a darker surface with elevated $\mathrm{pH}$ values and decreased oxygen penetration.

\section{Lipid oxidation}


Lipid oxidation, as determined by TBA measurements, revealed that TBARS decreased significantly $(\mathrm{p}<0.05)$ in GE and STPP marinated samples $(0.14 \& 0.12 \mathrm{mg} \mathrm{mal} / \mathrm{kg}$, respectively) compared to control and LJ marinated samples $(0.19$ \& $0.20 \mathrm{mg} \mathrm{mal} / \mathrm{kg}$, respectively) for raw samples (Table 1). These results were in harmony with that obtained by Lee et al. (1986) and Ke et al. (2009). Furthermore, Jimenez-Villarreal et al. (2003) hypothesized that $\mathrm{pH}$ of treated meat was related to TBA-value the higher the $\mathrm{pH}$, the less lipid oxidation the samples had). On the other side, it was found that the TBARS of all cooked marinated samples (Table 2) were significantly lower $(\mathrm{p}<0.05)$ than the control $(0.57 \mathrm{mg} \mathrm{mal} / \mathrm{kg})$. Moreover, STPP marinated samples $(0.13 \mathrm{mg} \mathrm{mal} / \mathrm{kg})$ showed marked reduction in TBARS compared with the GE and LJ marinated samples $(0.23 \& 0.27$ $\mathrm{mg} \mathrm{mal} / \mathrm{kg}$, respectively), while no difference could be found between GE and LJ marinated samples. The increase in TBARS of GE cooked marinated samples may be referred to the time/temperature treatment used for cooking the samples (Lee et al., 1986).

\section{Elechtrophoretic pattern of muscle protein}

mol.w.

$\begin{array}{llllllllllll}\text { (KDs) } & \mathrm{M} & \mathrm{A} & \mathrm{A} & \mathrm{B} & \mathrm{B} & \mathrm{C} & \mathrm{C} & \mathrm{D} & \mathrm{D}\end{array}$

Fig. 1: Electrophoretic pattern of control (A), GE (B), LJ (C), STPP (D) marinated samples and protein marker $(\mathrm{M})$.

A representative SDS-PAGE gel elechtrophorsis of the marinated and control samples (fig. 1) proved significant reduction $(\mathrm{p}<0.05)$ of 
protein bands in GE and LJ marinated samples compared with the control and STPP marinated samples. This could be attributed to the effect of protease (zingibain) in ginger extract which degrades muscles collagen and myofibril (Lee et al., 1986; Adulyatham and Apenten, 2004 and Pawar et al., 2007). The obtained results were in harmony with that recoded by Sachindra et al. (2006) and Naveena et al. (2004). Regarding LJ marinated samples, Burke and Monahan (2003) indicated that the tenderization of beef samples using citrus juice marinade could be attributed to marinade uptake by muscle proteins and also to solubility of collagen. Moreover, acidic marinades denature proteins, as the bonds between protein bundles in the meat break and the proteins unwind and run into each other to form a loose mesh. STPP marinated and control samples showed no proteolytic effect evidently by no significant differences $(p<0.05)$ in the electrophoretic pattern among these samples.

\section{APC and P BC}

It was obvious that there was a significant reduction $(\mathrm{p}<0.05)$ in the APC and PBC in LJ marinated samples $\left(<10^{2} \mathrm{CFU} / \mathrm{g}\right)$ followed by STPP marinated samples (3.47 \& $2.28 \log _{10}$ CFU/g, respectively) as compared with GE marinated samples (4.93 \& $5.03 \log _{10}$ CFU/g, respectively) and control samples(3.94 \& $3.72 \log _{10} \mathrm{CFU} / \mathrm{g}$, respectively) (Table 1). This may be referred to the existence of high concentrations of citric acid in LJ up to $8 \%$ of their dry weight (Penniston et al., 2008) which acidified marinated meat and reduced the risk of bacterial contamination. Antibacterial activity of citric acid is dependent on $\mathrm{pH}$, concentration and anion effects (Mohamed et al., 2008). Similar results were recorded by Mahrour et al. (2003) and Kanellos and Burried (2005) who stated that $\mathrm{pH}$ values observed after treatment with alkaline phosphate and citric acid are within ranges that inhibit the multiplication of most bacteria, thus adding to the bactericidal effect of both these compounds. On the other hand, the unexpectedly higher APC (4.93 $\log _{10}$ $\mathrm{CFU} / \mathrm{g})$ and $\mathrm{PBC}\left(5.03 \log _{10} \mathrm{CFU} / \mathrm{g}\right)$ of GE marinated samples by one $\log$ cycle than those of the control $(3.94 \& 3.72 \mathrm{CFU} / \mathrm{g}$ for APC \& PBC, respectively). This increase in bacterial count may be attributed to the degree of contamination of fresh ginger purchased from local market and manual preparation of the extract.

\section{Shear force, Cooking loss and Sensory evaluation}

Although the shear force values were significantly reduced $(\mathrm{p}<$ 0.05) in all marinated samples $(10.28,10.57$ and $9.67 \mathrm{~kg}$ f for GE, LJ 
and STPP marinated samples, respectively) compared with the control (19.84 kg f), no significant difference ( $\mathrm{p}<0.05$ ) was seen among marinated samples (Table 2). Reduction in shear force values with GE marinated samples could be attributed to the effect of zingibain (protease) in GE, which was reported in buffalo by Syed Ziauddin et al. (1995) and Naveena et al. (2004) and in spent hen meat by Naveena and Mendiratta (2001) and Sachindra et al. (2006). Moreover, Davis et al. (2004) reported significantly lower shear force values for injected fresh pork loins than uninjected samples. Looking for cooking loss (Table 2), a significant reduction $(\mathrm{p}<0.05)$ was observed in STPP marinated samples $(25.01 \%)$ compared to the control (39.01) and other marinated samples (42.67 \& 39.99\% for GE \& LJ marinated samples, respectively), similar results were recorded by Baublits et al. (2005). However, in samples marinated with GE and LJ the cooking loss didn't differ significantly $(p<0.05)$ than that of the control samples.

\section{Sensory evaluation}

Results of the sensory taste panel analysis for different marinades are reported in Table (2). Sensory panelists found that tenderness, flavour, juiciness and overall acceptability were significantly improved $(\mathrm{p}<0.05)$ with marination. STPP and GE marinated samples recorded the highest tenderness scores (7.5 and 7.17, respectively), followed by LJ marinated samples (6.83). These results are in agreement with Brashear et al. (2002) and Smith et al. (2002) who found that the use of a $\mathrm{NaCl} / \mathrm{STPP}$ solution increased tenderness in enhanced pork lion in comparison to the non-enhanced control. Regarding juiciness, STPP and GE marinated samples ( $7.67 \& 7$, respectively) were significantly higher $(\mathrm{p}<0.05)$ than that of control (3.5), and LJ marinated samples (5.67). This could be explained on the base that alkaline STPP interact with muscle proteins and increase their ability to hold moisture inside meat during cooking, which increases the juiciness of the cooked meat (Brooks, 2007). In this respect, Naveena et al. (2004) pointed out that the alkalinity of GE marinated samples help protein in keeping its water. While $\mathrm{pH}$ of LJ marinated samples (4.62) was near isoelectric point so that it's protein becomes unable to hold water. It's worth mentioning that the electrophoretic pattern emphasis the higher tenderness, juiciness score and lower shear force value in GE marinated samples. The flavour of both GE and LJ marinated samples (6.67\& 7.17, respectively) had significant pleasant flavour $(\mathrm{p}<0.05)$ than that of control (4) and STPP marinated samples (5.5). This could be attributed to flavoring substances in both GE and LJ (ICMR, 2003 and Bauermeister and Mckee, 2005). 
Taste panel proved that GE marinated samples obtained excellent overall acceptability followed by LJ, STPP marinated and control samples.

In conclusion, the results obtained in this study clearly indicate the tenderizing effect of GE, LJ and STPP (in combination with 1.5\% $\mathrm{NaCl}$ ) to improve tenderness of buffalo meat and overall quality characteristics. Therefore, GE and LJ provide a cheap, safe and easy method that can be used effectively to tenderize and improve quality of buffalo meat, at both industrial and household level.

\section{REFERENCES}

Adulyatham, P. and Apenten, R. (2004): Stabilization and Partial Purification of a Protease from Ginger Rhizome (Zingiber offinale Roscoe). Food Sci., 70 (3): C231 - C234

Aktas, N.; Aksu, M.I. and Kaya, M. (2004): The effect of organic acid marination on tenderness, cooking loss and bound water content of beef. J. Muscle Foods, 181-194.

AOAC (1990): Association of Official Analytical Chemists: Official Methods of Analysis (13th ed.) Arlington, VA, USA.

APHA (1992): American Public Health Association: Compendium of Methods for the Microbiological Examination of Foods. $3^{\text {rd }}$ ed Washington.

Baublits, R.T.; Pohlman, F.W.; Brown, A.H., Jr. and Johnson, Z.B. (2005): Effects of enhancement with varying STPP types and concentrations, at two different pump rates on beef biceps femoris instrumental color characteristics. Meat Sci., 71: 264276.

Baublits, R.T.; Pohlman, F.W.; Brown, A.H.; Yancey, E.J. and Johnson, Z.B. (2006): Impact of muscle type and sodium chloride concentration on the quality, sensory and instrumental color characteristics of solution enhanced whole-muscle beef. Meat Sci., 72: 704-712.

Bauermeister, L.J. and McKee, S.R. (2005): Utilizing marination and vacuum tumbling techniques to optimize tenderness of breast fillets deboned early postmortem. XVII ${ }^{\text {th }}$ European Symposium on the Quality of Poultry Meat. Doorwerth, The Netherlands, 23-26. 
Brashear, M.S.; Brewer, D.; Meisinger F.K. and McKeith, F.K. (2002):

Raw materials and pump improves pork. J. Muscle Foods, 13: 189-204.

Brooks, J.C. (2007): Marinating of beef for enhancement. , Cattlemen's Beef Board. www.beefresearch.org.

Burke, R.M. and Monahan, F.J. (2003): The tenderisation of shin beef using a citrus juice marinade. Meat Sci., 63: 161-168.

CIE (1978): Commission Internationale de 1_eclairage: Recommendation on uniform color spaces-color difference equations; psychometric color terms. Supplement No. 2 to CIE Publication No. 15 (E-1.3.1)1971/(TC-1-3). Paris, France.

Davis, K.J.; Sebranek, J.G.; Huff-Lonergan, E.; Ahn, D.U. and Lonergan, S.M. (2004): The effects of irradiation on quality of injected fresh pork loins. Meat Sci., 67: 395-401.

FAO (2004): Food and Agriculture Organization: Buffalo Newsletter/Europe-Near East1993-2003. FAO/RNE- Regional office for the Near East Cairo 2004.

Faustman, C. and Cassens, R.G. (1990): The biochemical basis for discoloration in fresh meat. a review. J. Muscle Foods, 1: 217243.

ICMR (2003): Indian Council of Medical Research. Ginger; its role in xenobiotic metabolism., Offset Press, New Delhi-110 029. 33(6): 56

Jimenez-Villarreal, J.R.; Pohlman, F.W.; Johnson, Z.B.; Brown Jr., A.H. and Baublits, R.T. (2003): The impact of single antimicrobial intervention treatment with cetylpyridinium chloride, trisodium phosphate, chlorine dioxide or lactic acid on ground beef lipid, instrumental color and sensory characteristics. Meat Sci., 65: 977-984.

Kanellos, T.S. and Burriel, A.R. (2005): The in vitro bactericidal effects of the food decontaminants lactic acid and trisodiumpolyphosphate. Food Microbiol., 22: 591-594.

Keeton, J.T. (1983): Effect of fat and $\mathrm{NaCl} /$ sodiumpolyphosphates level on the chemical and sensory properties of pork patties. Food Sci., 48: 878-881.

Ke, S.; Yan, H.; Eric A. and Hultin D.O. (2009): Impact of citric acid on the tenderness, microstructure and oxidative stability of beef muscle. Meat Sci., 82: 113-118.

Laemmli, U.K. (1970): Cleavage of structural proteins during the assembly of head of bacteriophage $\mathrm{T}_{4}$. Nature, 227: 680-685. 
Lee, B.J.; Hendricks, D.G. and Cornforth, D.P. (1998): Effect of sodium phytate, sodium pyrophosphate and sodium tripolyphosphate on physico-chemical characterietics of restructured beef. Meat. Sci., 50: 273-283.

Lee, Y.B.; Kim, Y.S. and Ashmor, C.R. (1986): Antioxidant property in ginger rhizome and its application to meat products. J. Food Sci., 51: 20-23.

Mahrour, A.; Caillet, S.; Nketsia-Tabiri, J. and Lacroix, A. (2003): The antioxidant effect of natural substances on lipids during irradiation of chicken legs. J. A.O.C.S., 80: 679.

McGee, M.R.; Henry, K.L.; Brooks, J.C.; Ray, F.K.; and Morgan, J. B. (2003): Injection of sodium chloride, sodium tripolyphosphate, and sodium lactate improves Warner-Bratzler shear and sensory characteristics of pre-cooked inside round roasts. Meat Sci., 64: 273-277.

Mohamed Jamilah, B.; Abbas, K.A. and Abdul Rahman, R. (2008): A Review on Some Organic Acids Additives as Shelf Life Extenders of Fresh Beef Cuts. Am. J. Agri. \& Biol. Sci., 3: 566-574.

Naveena, B.M. and Mendiratta, S.K. (2001): The tenderization of buffalo meat using GINGER extract. J. Muscle Foods, 15: 235246.

Naveena, B.M.; Mendiratta, S.K. and Anjaneyulu, A.S.R. (2004): Tendexization of buffalo meat using plant proteases from Cucumis trigonus roxb (kachri) and Zingiber officinale roscoe (ginger rhizome). Meat Sci., 68: 363-369.

Northcutt, J.K. (1999): Marination and water-holding capacity of broiler meat. cooperative extension service College of agricultural and environmental sciences / Athens, Georgia 30602-4356, University of Georgia.

Pawar, V.D.; Mule, B.D. and Machewad, G.M. (2007): Effect of marination with ginger rhizome extract on properties of raw and cooked chevon. J. Muscle Foods, 18: 349 - 369

Pearson, A.M. and Gillett, T. A. (1996): Ch. 11. Extenders and Binders in Processed Meats. 3rd Ed.Chapman and Hall. New York, NY. P 291-310.

Penniston, K.L.; Nakada, S.Y.; Holmes, R.P.and Assimos, D.G. (2008): Quantitative Assessment of Citric Acid in LJ Juice, Lime Juice, and Commercially-Available Fruit Juice Products. J. Endourology, 22: 567. 
Rio, E.D.; Panizo-Moran, M.; Prieto, M.; Alonso-Calleja, C. and Capita, R. (2007): Effect of various chemical decontamination treatments on natural microflora and sensory characteristics of poultry. Int. Food Microbiol., 115: 268-280.

Robbins, K.; Jensen, J.; Ryan Homco-Ryan McKeith, F.K. and Brewer, M.S. (2002): Enhancement effects on sensory and retail display characteristics of beef rounds. J. Muscle Foods, 13: 279-288.

Robbins, K.; Jensen, J.; Ryan, K.J.; Homco-Ryan, C.; McKeith, F.K. and Brewer, M.S. (2003): Consumer attitudes towards beef and acceptability of enhanced beef. Meat Sci., 65: 721-729.

Ronald, S.K. and Ronald, S. (1991): Pearson's, Composition and Analysis of Foods. $g^{\text {th }}$ ed. Longman scientific and technical

Rust, R.E. (1998): Marketing opportunities for enhanced fresh pork. Meat International, 8(10): 36-39.

Sachindra, B.N.M.; Modi, V.K.; Sakhare, P.Z.; and Mahendrakar, N.S. (2006): Preparation of proteolytic activity rich GINGER powder and evaluation of its tenderizing effect on spent-hen muscles. J. Muscle Foods, 17: 174-181.

SAS (1990): Statistical Analysis System. Campus Drive, Carys, NC.27513, USA. SAS Institute Inc.

See, Y.P. and Jackowski, S. (1993): Estimating molecular weights of polypeptides by SDS gel electrophoresis. In T. E. Creighton (Ed.), Protein structure, a practical approach pp.1-15. Oxford. IRL Press.

Smith, K.R.; Scanga, J.A.; Belk, K.E. and Smith, G.C. (2002): Tenderness and sensory traits of branded, enhanced and nonenhanced pork loin hops. Animal Sciences Research Report. Department of Animal Sciences, Colorado State University

Swatland, H.J. (1993): Paleness, Softness and Exudation in Pork Review. In Pork Quality. Genetic and Metabolic Factors. Eds. E. Puolanne and D. I. Demeyer. Pgs. 273-286. citaed after Bauermeister, L.J. and McKee, S.R. (2005)

Syed Ziauddin, K.; Rao, D.N. and Amla, B.L. (1995): Effect of lactic acid, GINGER extract and sodium chloride on electrophoretic pattern of buffalo muscle proteins. Food Sci and Technol., 32: 224-226.

Thompson, E.H.; Wolf, I.D. and Allen, C.E. (1973): Ginger rhizome: A new source of proteolytic enzymes. J. Food Sci., 38: 652-655. 
Vote, D.J.; Platter, W.J.; Tatum, J.D.; Schmidt, G.R.; Belk, K.E.; Smith, G.C., et al. (2000): Injection of beef strip loins with solutions containing sodium tripolyphosphate, sodium lactate, and sodium chloride to enhance palatability. J. Animal Science, 78: 952-95

Vyncke, W.C. (1970): Direct determination of the thiobarbituric acid extract of fish as a mean of oxidative rancidity. Fette. Seifen. Ansti- Chmitted, 27: 1084.

Wicker, L.; Harrison,M.; Huang, Y.; Kerr, W.; Reynolds, E.; Toliedo,R. Et al (1999): Marination technology and process, product and ingredient interaction.project No. FP98-PC02. The University of Georgia, (706) 542-1055.

Yoon, K.S. (2003): Effect of gamma irradiation on the texture and microstructure of chicken breast meat. Meat Sci., 63: 273-277. 